\title{
Urinary incontinence after vaginal delivery or cesarean section
}

\author{
Incontinência urinária após parto vaginal ou cesáreo
}

\author{
João Bosco Ramos Borges ${ }^{1}$, Telma Guarisi², Ana Carolina Marchesini de Camargo ${ }^{3}$, Thomaz Rafael Gollop ${ }^{4}$, \\ Rogério Bonassi Machado ${ }^{5}$ Pítia Cárita de Godoy Borges ${ }^{6}$
}

\begin{abstract}
Objective: To assess the prevalence of stress urinary incontinence, urge incontinence and mixed urinary incontinence among women residing in the city of Jundiaí (São Paulo, Brazil), and the relation between the type of incontinence and the obstetric history of these women. Methods: A cross-sectional community-based study was conducted. A total of 332 women were interviewed; they were seen for whatever reason at the public primary healthcare units of the city of Jundiaí, from March 2005 to April 2006. A pre-tested questionnaire was administered and consisted of questions used in the EPINCONT Study (Epidemiology of Incontinence in the County of Nord-Trondelag). Statistical analysis was carried out using the $\chi^{2}$ test and odds ratio $(95 \% \mathrm{Cl})$. Results: Urinary incontinence was a complaint for $23.5 \%$ of the women interviewed. Stress urinary incontinence prevailed $(50 \%)$, followed by mixed urinary incontinence $(35 \%)$ and urge incontinence $(15 \%)$. Being in the age group of 35-64 years, having a body mass index of 30 or greater and having had only vaginal delivery or cesarean section, with uterine contraction, regardless of the number of pregnancies, were factors associated with stress urinary incontinence. However, being in the age group of 55 or older, having a body mass index of 30 or greater and having had three or more pregnancies, only with vaginal deliveries, were factors associated with mixed urinary incontinence. Conclusions: One third of the interviewees complained of some type of urinary incontinence, and half of them presented stress urinary incontinence. Cesarean section, only when not preceded by contractions, was not associated with stress urinary incontinence. The body mass index is only relevant when the stress factor is present.
\end{abstract}

Keywords: Urinary incontinence; Natural childbirth; Cesarean section; Cross-sectional studies; Questionnaires

\section{RESUMO}

Objetivo: Avaliar a prevalência de incontinência urinária de esforço, urge incontinência e incontinência urinária mista entre mulheres residentes no município de Jundiaí, e a relação entre o tipo de incontinência e história obstétrica dessas mulheres. Métodos: Foi realizado estudo de corte transversal, do tipo inquérito populacional, no qual foram entrevistadas 332 mulheres, que compareceram por qualquer motivo às unidades básicas de saúde do município de Jundiaí, entre Março de 2005 e Abril de 2006. Para isso, foi utilizado um questionário pré-testado contendo questões utilizadas no EPINCONT Study (Epidemiology of Incontinence in the County of NordTrondelag). A análise estatística foi realizada utilizando-se o teste do $\chi^{2}$ e odds ratio (IC95\%). Resultados: A queixa de incontinência urinária foi observada em $23,5 \%$ das mulheres entrevistadas, sendo que a incontinência urinária de esforço foi a mais prevalente (50\%), seguida pela incontinência urinária mista $(35 \%)$ e urge-incontinência (15\%). Ter idade entre 35 e 64 anos, índice de massa corpórea maior ou igual a 30 e ter passado apenas por parto normal ou cesárea, com contração, independentemente do número de gestações, foram fatores associados à incontinência urinária de esforço. Já idade acima de 55 anos, índice de massa corpórea maior ou igual a 30 , ter passado por três ou mais gestações apenas com partos normais associaram-se à incontinência urinária mista. Conclusões: Um terço das mulheres entrevistadas queixava-se de algum tipo de incontinência urinária, sendo que a metade delas apresentava

\footnotetext{
Study carried out at the Department of Gynecology and Obstetrics of Faculdade de Medicina de Jundiaí - FMJ, Jundiai (SP), Brazil.

${ }^{1}$ PhD; Full Professor at Faculdade de Medicina de Jundiaí - FMJ, Jundiaí (SP), Brazil.

${ }^{2} \mathrm{PhD}$ at Universidade Estadual de Campinas - UNICAMP, Campinas (SP), Brazil.

${ }^{3} \mathrm{PhD}$ student at Faculdade de Medicina de Ribeirão Preto of Universidade de São Paulo - USP, Ribeirão Preto (SP), Brazil; Assistant Professor at Faculdade de Medicina de Jundiaí - FMJ, Jundiaí (SP), Brazil.

${ }^{4}$ Full professor; Associate Professor at Faculdade de Medicina de Jundiaí - FMJ, Jundiaí (SP), Brazil

${ }^{5}$ PhD; Adjunct Professor at Faculdade de Medicina de Jundiaí - FMJ, Jundiaí (SP), Brazil.

${ }^{6}$ Master degree at Faculdade de Medicina of Universidade Estadual Paulista "Júlio de Mesquita Filho" - UNESP, Botucatu (SP), Brazil; Volunteer Professor at Faculdade de Medicina de Jundiaí - FMJ, Jundiaí (SP), Brazil.

Corresponding author: João Bosco Ramos Borges - Rua Francisco Telles, 250 - Vila Arens - CEP 13202-550 - Jundiaí (SP), Brasil - Tel.: 4587-1095/9989-7818 - e-mail: drbosco@terra.com.br

Received on Oct 6, 2009 - Accepted on Apr 12, 2010

The authors declare no conflict of interest.
} 
incontinência urinária de esforço. 0 parto cesáreo, apenas quando não precedido de contrações, não se associou à incontinência urinária de esforço. 0 índice de massa corpórea demonstrou ser importante apenas quando há o componente esforço.

Descritores: Incontinência urinária; Parto normal; Cesárea; Estudos transversais; Questionários

\section{INTRODUCTION}

Urinary incontinence is defined by the International Continence Society (ICS) as any involuntary urine loss ${ }^{(1)}$. The prevalence of urinary incontinence varies much, according especially to the type of population and the different age groups investigated. It is more frequent in women than men, and it is estimated that one in every four women have some type of urinary loss(2). In the city of Campinas, São Paulo, Brazil, by means of a population enquiry, we observed that $35 \%$ of women aged 45-60 years had stress urinary incontinence (SUI) complaints $^{(3)}$.

Among the many types of urinary incontinence in women, the most frequent is SUI, defined as involuntary urine loss during some physical exertion, sneeze or cough ${ }^{(1)}$. The second most frequent cause stems from hyperactivity of the detrusor muscle, mainly represented by urge incontinence (UI), that is involuntary urine loss associated with a strong urge to void urine. Often times, we find an association of both types of complaints characterizing the mixed urinary incontinence (MUI).

Pregnancy and delivery are the main risk factors associated with SUI, especially during the reproductive years ${ }^{(4-7)}$, particularly vaginal delivery ${ }^{(8)}$, due to the damage that it can cause to integrity of muscles and nerves of the pelvic floor. These muscles and nerves represent an important factor in maintenance of urinary continence.

The arguments used to justify the lack of protection caused by a C-section include physiological alterations brought by pregnancy, such as changes to anatomical relations between the bladder and the uterus, reduced strength of the fascia that anchors the bladder neck, high levels of progesterone and bladder instability ${ }^{(9-10)}$.

On the contrary, other findings point to meaningless incontinence rates in patients with a history of a C-section when compared to those who underwent vaginal delivery ${ }^{(9-11)}$.

One of the limitations of this study is that when using the patients who had underwent C-Sections, it was not considered whether or not the delivery happened after a period of labor or if it was an elective indication, not preceded by uterine contractions.

\section{OBJECTIVES}

To assess the prevalence of stress urinary incontinence, urge incontinence and mixed urinary incontinence among women residing in the city of Jundiaí, São Paulo, Brazil, as well as the association between the type of urinary incontinence and the obstetric history.

\section{METHODS}

We interviewed 332 women of, at least, 16 years of age, who came for any reason (as companions to family members or going to appointment with any other medical specialist) to the primary healthcare units, in the period between March 2005 and April 2006; they answered questions associated with urinary incontinence, in a cross-sectional study - enquiry type, on women's health, in the city of Jundiaí. We used a pretested questionnaire with questions used in the EPINCONT Study (Epidemiology of Incontinence in the Country of Nord-Trondelag). Such questions on urinary incontinence included: SUI, defined as the loss of urine during exertion such as coughing, laughing and/or bearing weights; UI, when the woman reports urinary loss associated with micturition urgency; MUI, when the woman reports urinary loss upon exertion associated with urge incontinence or micturition urgency (uncontrollable urge to urinate), with urinary frequency (number of micturitions per day), dysuria (pain upon urination) and nocturia (more than two urinations during the night). The obstetric history includes number of gestations, type of delivery (vaginal only, c-section only, vaginal and c-section) and whether or not the woman was in labor before C-sections. Other variables investigated were age, body mass index (BMI) and smoking. For statistical analysis, the $\chi^{2}$ test and odds ratio $(95 \% \mathrm{CI})$ were used.

This project was approved by the Research Ethics Committee of Faculdade de Medicina de Jundiaí FMJ.

\section{RESULTS}

Of the 332 women interviewed, almost one quarter complained of some type of urinary loss (Figure 1).

The main type of urinary incontinence reported was SUI, complained by half of the women (Figure 2).

The group of women with no complaint of urinary loss was used as control to compare the different variables analyzed with the type of urinary incontinence. Of all factors analyzed, we observed that age between 35 and 64 years, BMI greater than or equal to 30 and having had, at least, one gestation, showed a positive association with the complaint of SUI (Table 1). 
Urinary Incontinence

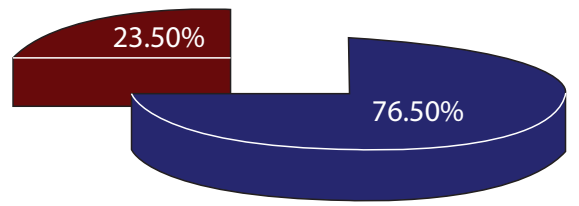

Figure 1. Distribution of women per presence of urinary incontinence
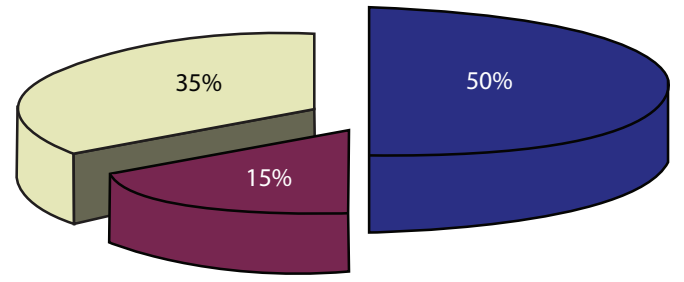

SUI: stress urinary incontinence; UI: urge incontinence; MUI: mixed urinary incontinence

Figure 2. Percentage distribution of women per type of urinary incontinence

Table 1. Factors associated to complaint of stress urinary incontinence

\begin{tabular}{|c|c|c|c|c|}
\hline \multirow{2}{*}{ Factors } & \multicolumn{2}{|c|}{$\mathbf{n}$} & \multirow{2}{*}{ OR } & \multirow{2}{*}{$95 \% \mathrm{Cl}$} \\
\hline & $N / C$ & SUI & & \\
\hline \multicolumn{5}{|c|}{ Age (years) } \\
\hline 16-34 & 110 & 3 & Ref. & \\
\hline $35-44$ & 46 & 11 & 8.77 & (2.13-50.48) \\
\hline $45-54$ & 40 & 14 & 12.83 & (3.28-71.99) \\
\hline $55-64$ & 32 & 6 & 6.88 & $(1.36-44.12)$ \\
\hline 65 or + & 18 & 2 & 4.07 & $(0.31-37.63)$ \\
\hline Total & 247 & 36 & & \\
\hline
\end{tabular}

$\mathrm{BMI}$

$\begin{array}{lcccc}<30 & 200 & 22 & \text { Ref. } & \\ \geq 30 & 35 & 13 & 3.38 & (1.45-7.81) \\ \text { Total } & 235 & 35 & & \end{array}$

Smoking

$\begin{array}{lcccc}\text { No } & 158 & 17 & \text { Ref. } & \\ \text { Yes } & 88 & 18 & 1.9 & \text { (0.88-4.1) } \\ \text { Total } & 246 & 35 & & \end{array}$

Number of gestations

\begin{tabular}{lcccc} 
None & 56 & 1 & Ref. & \\
$1-2$ & 87 & 17 & 10.94 & $(1.61-465.32)$ \\
3 or + & 104 & 18 & 9.69 & $(1.44-410.9)$ \\
Total & 247 & 36 & & \\
\hline
\end{tabular}

N/C: no complaints; SUl: stress urinary incontinence; OR: odds ratio; 95\%Cl: confidence interval of 95\%; BMI: body mass index; Ref: reference value.

As far as UI is concerned, there was no significant association with any of the variables analyzed (Table 2).

Concerning women who complained of SUI and UI, a significant association with age above 55 years, BMI equal to or greater than 30 and having had three or more gestations were observed (Table 3).
Table 2. Factors associated to complaint of urge incontinence

\begin{tabular}{|c|c|c|c|c|}
\hline \multirow{2}{*}{ Factors } & \multicolumn{2}{|c|}{$\mathbf{n}$} & \multirow{2}{*}{ OR } & \multirow{2}{*}{$95 \% \mathrm{CI}$} \\
\hline & $\mathrm{N} / \mathrm{C}$ & UI & & \\
\hline \multicolumn{5}{|c|}{ Age (years) } \\
\hline $16-34$ & 110 & 5 & Ref. & \\
\hline $35-44$ & 46 & 1 & 0.48 & $(0.01-4.46)$ \\
\hline $45-54$ & 40 & 2 & 1.1 & $(0.10-7.05)$ \\
\hline $55-64$ & 32 & 2 & 1.38 & $(0.13-8.88)$ \\
\hline 65 or + & 18 & 1 & 1.22 & $(0.02-11.86)$ \\
\hline Total & 247 & 11 & & \\
\hline \multicolumn{5}{|l|}{ BMl } \\
\hline$<30$ & 200 & 10 & Ref. & \\
\hline$\geq 30$ & 35 & 0 & $\begin{array}{c}\text { Not } \\
\text { calculable }\end{array}$ & \\
\hline Total & 235 & 10 & & \\
\hline \multicolumn{5}{|l|}{ Smoking } \\
\hline No & 158 & 6 & Ref. & \\
\hline Yes & 88 & 5 & 1.5 & $(0.35-6.06)$ \\
\hline Total & 246 & 11 & & \\
\hline
\end{tabular}

Number of gestations

$\begin{array}{lcccc}\text { None } & 56 & 1 & \text { Ref. } & \\ 1-2 & 87 & 5 & 3.32 & (0.34-154.89) \\ 3 \text { or }+ & 104 & 5 & 2.69 & \text { (0.29-129.58) } \\ \text { Total } & 247 & 11 & & \end{array}$

N/C: no complaints; Ul: urge incontinence; OR: odds ratio; 95\%Cl: confidence interval of 95\%; BMl: body mass index; Ref: reference value.

Table 3. Factors associated to mixed urinary incontinence

\begin{tabular}{|c|c|c|c|c|}
\hline \multirow{2}{*}{ Factors } & \multicolumn{2}{|c|}{$\mathbf{n}$} & \multirow{2}{*}{$\mathbf{O R}$} & \multirow{2}{*}{$95 \% \mathrm{Cl}$} \\
\hline & $\mathrm{N} / \mathrm{C}$ & MUI & & \\
\hline \multicolumn{5}{|l|}{ Age (years) } \\
\hline $16-34$ & 110 & 3 & Ref. & \\
\hline $35-44$ & 46 & 2 & 1.59 & (0.13-14.35) \\
\hline $45-54$ & 40 & 5 & 4.58 & $(0.84-30.51)$ \\
\hline $55-64$ & 32 & 11 & 12.6 & $(3.02-73.06)$ \\
\hline 65 or + & 18 & 4 & 8.15 & $(1.24-58.84)$ \\
\hline Total & 247 & 25 & & \\
\hline \multicolumn{5}{|l|}{ BMl } \\
\hline$<30$ & 200 & 14 & Ref. & \\
\hline$\geq 30$ & 35 & 8 & 3.27 & $(0.15-9.11)$ \\
\hline Total & 235 & 22 & & \\
\hline \multicolumn{5}{|l|}{ Smoking } \\
\hline No & 158 & 13 & Ref. & \\
\hline Yes & 88 & 12 & 1.66 & $(0.67-4.07)$ \\
\hline Total & 246 & 25 & & \\
\hline \multicolumn{5}{|c|}{ Number of gestations } \\
\hline None & 56 & 1 & Ref. & \\
\hline $1-2$ & 87 & 6 & 3.86 & $(0.45-180.76)$ \\
\hline 3 or + & 104 & 18 & 9.69 & $(1.44-410.9)$ \\
\hline Total & 247 & 25 & & \\
\hline
\end{tabular}

N/C: no complaints; MUI: mixed urinary incontinence; OR: odds ratio; $95 \% \mathrm{Cl}$ : confidence interval of 95\%; BMI: body mass index; Ref: reference value. 
When the groups were compared as to mode of delivery, having had only vaginal delivery or only $\mathrm{C}$-section preceded by uterine contractions also had positive association with SUI. Having had only vaginal delivery was also positively associated with MUI (Table 4). The mode of delivery, regardless of being preceded by uterine contractions or not, was not associated with UI (these data are not shown on a table).

Table 4. Comparison between mode of delivery with different complaints of urinary incontinence

\begin{tabular}{lccccc}
\hline Delivery & \multicolumn{3}{c}{ Complaint } & \multicolumn{3}{c}{ OR (95\%Cl) } \\
\cline { 2 - 6 } & N/C & SUI & MUI & SUI & MUI \\
\hline None & 56 & 1 & 1 & Ref. & Ref. \\
Only vaginal & 105 & 16 & 17 & $8.53(1.25-364.12)$ & $9.07(1.34-385.56)$ \\
Only C-section & 46 & 6 & 2 & $7.3(0.83-341.94)$ & $2.43(0.12-146.16)$ \\
With & 19 & 4 & 1 & $11.79(1.04-590.57)$ & $2.95(0.04-235.39)$ \\
contractions & & & & & \\
Without & 27 & 2 & 1 & $4.15(0.2-248.99)$ & $2.07(0.03-165.66)$ \\
contractions & & & & & \\
Total & 207 & 22 & 19 & & \\
\hline
\end{tabular}

$\mathrm{N} / \mathrm{C}$ : no complaints; SUl: stress urinary incontinence; MUI: mixed urinary incontinence; OR: odds ratio; $95 \% \mathrm{Cl}$ : confidence interval; Ref: reference value.

\section{DISCUSSION}

Urinary incontinence is a common problem that affects women during the menacme and menopause. It is associated with a loss of independence and decreased quality of life, limiting the individual's participation in domestic and social activities. The SUI prevalence data vary considerably, depending on the age group, the characteristics of the population and the diagnostic criteria used. It varies from 12 to $56 \%^{(3,12-14)}$. The prevalence of urinary incontinence is scarcely studied in Brazil. Understanding urinary symptoms, associated factors, with emphasis on the mode of delivery was the goal of the questionnaire assessment done in this sample.

In a study held by means of interviews with Brazilian men and women aged 55 years or older, a greater prevalence was found among women $(43 \%)^{(15)}$. The data of the present study showed that approximately one in every four women interviewed reported some kind of urinary loss, which is in agreement with the results recently described by Contreras Ortiz ${ }^{(2)}$.

Among the urinary incontinence types, the most frequently found in this study was SUI, reported by approximately half of the women who complained, followed by MUI - reported by one third of them. UI was found in $15 \%$ of women with any type of urinary incontinence.

Among the many factors that can be associated to the prevalence of urinary incontinence, race and smoking had no significant association in the present study. These results are in agreement with other studies ${ }^{(3)}$. On the other hand, BMI equal to or greater than 30 was significantly associated with SUI, differently from another study in which such association was not found ${ }^{(3)}$.

Previous studies observed an increase in UI prevalence with ageing, from 2 to $19 \%$, with a marked rise in people aged over 44 years $^{(16)}$. In the current study, MUI was significantly associated with age above 55 years. Regarding age, the group between 35 and 64 years was significantly associated to SUI. Nonetheless, this association was not found in the group aged above 65 years, which was also observed in previous studies ${ }^{(4)}$.

As to obstetric history, in this series there was a risk approximately 10-fold higher of developing SUI in patients with one or more pregnancies when compared to nulliparous women. Similar data was found in other studies ${ }^{(10-11)}$, and, in another Brazilian study, the risk was five times higher ${ }^{(10)}$. In such study, they worked with a hospital sample, and this fact could justify a lower prevalence, since it may be made up of women who are more prone to seek obstetric assistance. The present study assessed a population sample who went to the primary healthcare unit for any reason.

As to mode of delivery, there was a greater risk of SUI and MUI among women who had undergone only vaginal delivery. It was even more interesting to observe a higher risk of SUI among women who had only C-sections, which were preceded by labor. Meyer et al. ${ }^{(17)}$ also observed a lower prevalence of SUI in women submitted to elective C-section, as compared to those who had spontaneous vaginal delivery, and even lower among those in whom forceps was used (3,21 and $36 \%$, respectively).

However, contrary to the findings aforementioned, many studies showed a greater incidence of SUI in women submitted to vaginal delivery in comparison to those undergoing $\mathrm{C}$-section, and an even greater difference concerning nulliparous women ${ }^{(10-11,17)}$. Nevertheless, in all these studies, labor contractions before the $\mathrm{C}$-section were not evaluated, which can surely justify the differences found. It is known that labor per si can cause changes in the static of the pelvic floor, regardless of the mode of delivery, which is considered one of the main etiopathogenic factors associated with $\mathrm{SUI}^{(18)}$.

It is debatable whether pregnancy alone would be enough reason to cause impairments that could cause urinary incontinence. However, it is known that many women present this symptom during pregnancy and fail to report it after delivery ${ }^{(7,19)}$. It may be that these women present a greater risk of developing urinary incontinence in the future.

None of the variables considered was significantly associated with UI, maybe because of the reduced number of women with this symptom. The factors 
associated with pregnancy and delivery truly seem to be associated with SUI. Also MUI, which includes SUI, was significantly associated with vaginal delivery.

\section{CONCLUSIONS}

Results from the present study allowed us to conclude that the prevalence of urinary incontinence is high among women and that SUI affects especially women with a past history of delivery, even if it were a C-section; the labor seems to be the main factor associated with this complaint. Further studies are necessary in order to confirm these data and, especially, to assess other factors associated with delivery, which can contribute to the development of urinary incontinence. Having such knowledge, it is necessary to identify possible strategies to prevent or minimize this important problem that affects women.

\section{REFERENCES}

1. Abrams P, Artibani W, Cardozo L, Dmochowski R, van Kerrebroeck P, Sand P; International Continence Society. Reviewing the ICS 2002 terminologyreport: the ongoing debate. Neurourol Urodyn. 2009;28(4):287.

2. Contreras Ortiz 0. Stress urinary incontinence in the gynecological practice. Int J Gynaecol Obstet. 2004;86 Suppl 1:S6-16.

3. Guarisi T, Pinto-Neto AM, Osis MJ, Pedro A0, Costa-Paiva LH, Faúndes A. Incontinência urinária entre mulheres climatéricas brasileiras: inquérito domiciliar. J Public Health. 2001;35(5):428-35.

4. Rortveit G, Hannestad YS, Daltveit AK, Hunskaar S. Age- and type-dependent effects of parity on urinary incontinence: the Norwegian EPINCONT stydy. Obstet Gynecol. 2001;98(6):1004-10.

5. Chiarelli P, Brown W, McElduff P. Leaking urine: prevalence and associated factors in Australian women. Neurourol Urodyn. 1999;18(6):567-77.

6. Zhu L, Lang J, Liu C, Han S, Huang J, LiX. The epidemiological study of women with urinary incontinence and risk factors for stress urinary incontinence in China. Menopause. 2009;16(4):831-6.
7. Panayi DC, Khullar V. Urogynaecological problems in pregnancy and postpartum sequelae. Curr Opin Obstet Gynecol. 2009;21(1):97-100.

8. Milsom I, Ekelund P, Molander U, Arvidsson L, Areskoug B. The influence of age, parity, oral contraception, hysterectomy and menopause on the prevalence of urinary incontinence in women. J Urol. 1993;149(6):1459-62.

9. Rortveit G, Daltveit AK, Hannestad YS, Hunskaar S; Norwegian EPINCONT Study. Urinary incontinence after vaginal delivery or cesarean section. N Engl J Med. 2003;348(10):900-7.

10. Faúndes $A$, Guarisi T, Pinto-Neto AM. The risk of urinary incontinence of parous women who delivered only by cesarean section. Int $\mathrm{J}$ Gynaecol Obstet. 2001;72(1):41-6.

11. Herrmann V, Scarpa K, Palma PC, Riccetto CZ. Stress urinary incontinence 3 years after pregnancy: correlation to mode of delivery and parity. Int Urogynecol J Pelvic Floor Dysfunct. 2009;20(3):281-8.

12. Burgio KL, Matthews KA, Engel BT. Prevalence, incidence and correlates of urinary incontinence in healthy, middle-aged women. J Urol. 1991;146(5): $1255-9$.

13. Peyrat L, Haillot O, Bruyere F, Boutin JM, Bertrand P, Lanson Y. Prevalence and risk factors of urinary incontinence in young and middle-aged women. BJU Int. 2002;89(1):61-6.

14. Siracusano S, Pregazzi R, d'Aloia G, Sartore A, Di Benedetto P, Pecorari V, et al. Prevalence of urinary incontinence in young and middle-aged women in an Italian urban area. Eur J Obstet Gynecol Reprod Biol. 2003;107(2): 201-4.

15. Blanes L, Pinto Rde C, Santos VL. Urinary incontinence knowledge and attitudes in São Paulo. Ostomy Wound Manage. 2001;47(12):43-51.

16. Stewart WF, Van Rooyen JB, Cundiff GW, Abrams P, Herzog AR, Corey R, et al. Prevalence and burden of overactive bladder in the United States. World J Urol. 2003;20(6):327-36.

17. Meyer S, Schreyer A, De Grandi P, Hohlfeld P. The effects of birth on urinary continence mechanisms and other pelvic-floor characteristics. Obstet Gynecol. 1998:92(4 Pt 1):613-8.

18. Teleman PM, Gunnarsson M, Lidfeldt J, Nerbrand C, Samsioe G, Mattiasson A. Urethral pressure changes in response to squeeze: a population-based study in healthy and incontinent 53- to 63-year-old women. Am J Obstet Gynecol. 2003;189(4):1100-5.

19. Wesnes SL, Hunskaar S, Bo K, Rortveit G. The effect of urinary incontinence status during pregnancy and delivery mode on incontinence postpartum. A cohort study. BJOG. 2009;116(5):700-7. 